\title{
Comparative assessment of the regional strategies commitment to sustainable development goals
}

\author{
Marija Leuhova ${ }^{1}$, and Irina Korchagina ${ }^{2, *}$, and Ksenia Rogova $^{2}$ \\ ${ }^{1}$ Kemerovo State University, Institute of History and International Relations, 650056 Krasnaja ulica 6, \\ Russia \\ ${ }^{2}$ Kemerovo State University, Institute of Economics and Management, 650056 Krasnaja ulica 6, \\ Russia
}

\begin{abstract}
Sustainable development of the region is possible only if there is a development strategy focused on the goals and principles of sustainability. The purpose of the study is to develop a methodology for assessing the adherence of regional strategies to the principles of sustainable development and to test it. The methodology includes an analysis of the occurrence of keywords (descriptors) related to the essence and goals of sustainable development, comparative analysis, the use of the Wilcoxon T-test to assess the statistical significance of differences. The materials for the study are three options for the development strategy of the Kemerovo Region - Kuzbass for 2008, 2018, 2020. The results of the study showed that the commitment to sustainable development is growing. The occurrence of the corresponding descriptors increased by $40-50 \%$ during the development of a new version of the strategy. The 2018 version put more emphasis on good health and well-being, quality education, clean water, and responsible consumption and production compared to the previous version. In the 2020 version, the frequency of occurrence of descriptors related to water, responsible consumption and production, and the fight against climate change increased. Changes in the overall occurrence of sustainable development descriptors and the relationship between individual goals are explained by two reasons. The first reason is changes in the objective socio-economic situation in the region, such as an aging population or increased dependence on one industry (coal industry). The second factor is the change in the methodology used for developing the strategy. The use of strategy theory and strategy methodology allows you to balance the relationship between different goals of sustainable development.
\end{abstract}

\section{Introduction}

An important part of global and national sustainable development is the commitment of individual regions to the principles and goals of UN sustainable development. Large

\footnotetext{
* Corresponding author: korchagina-i@mail.ru
} 
economically developed regions of various growing countries, such as Russia, Brazil, India, China, contribute greatly to economic growth and welfare. However, many environmental problems can be observed in them, great social inequality can be manifested, and natural resources are depleted $[1,2]$.

For example, such industrial regions of Russia with a powerful primary sector of the economy, such as Kemerovo Oblast - Kuzbass, Krasnoyarsk Krai or Tyumen Oblast have accumulated many environmental problems [3]. They need to seriously change the model of socio-economic development, channeling part of the income from economic growth to achieve the sustainability of the economy, society and the environment. The basis for this should be the UN Sustainable Development Goals (as well as, in some cases, the Millennium Development Goals), modern scientific understanding of sustainable development.

As you know, the main directions of the socio-economic development of the region should be set by its strategy, reflected in the strategic planning documents [4]. For example, in Russia, each region, in accordance with the legislation, must develop a strategy for longterm socio-economic development (for a period of 10-20 years), as well as an action plan for its implementation. These documents need to be committed to the principles and goals of sustainable development. However, in practice this is often not done, therefore, regional strategies do not contribute to sustainable development (even if they are successfully implemented).

According to the authors, a necessary stage in analyzing and checking the quality of a regional strategy is to assess its adherence to the principles of sustainable development in order to understand how the region will approach sustainable development after the implementation of such a strategy. But the question of how to determine the degree of commitment of the strategy to the goals of sustainable development is now completely insufficiently studied. Decision-makers and the expert community can only on the basis of personal impressions and subjective assessments judge the degree of stability of the strategy.

The main focus of researchers around the world is directly on sustainable regional development, but not in conjunction with the problems of strategy development. It is worth noting the study by G. Haughton, D. Counsell, which examines how the term "sustainable development" was understood in the strategic plans of various regions of England. The authors demonstrated how the perceptions of policymakers about sustainable development have changed over the course of 10 years [5]. The same researchers showed that the existing mechanisms of strategic planning significantly hindered the integration of the goals of economic growth and sustainable development due to the divergence of national interests with regional ones [6].

C. Hirschi on the materials of Switzerland also established that a sustainable regional strategy can be developed only under the condition of broad network cooperation of all interest groups, local and regional network structures [7]. The same point of view is adhered to by A. Shahraki, in whose study, based on the materials of Iran, the importance of creating networks and collaborations for the development of sustainable strategies was demonstrated [8].

Another important area of research is the discussion of what criteria could demonstrate the commitment of regional strategies to sustainable development and what indicators can be used to measure progress towards achieving the goals of sustainable development. The most important among them is the criterion of continuous development and resistance to crises [9]. An idea was formed that regions are not only socio-economic, but also socioecological spaces, therefore sustainable strategies should contain sections on ecosystems, land management, the creation of closed waste-free industries, etc. [10]. 
There are studies that develop specific quantitative indicators that describe the level of sustainability of regional development, depending on various factors. J. Rezende, M. Sinay, in particular, developed an array of indicators most relevant to sustainable development goals based on direct interpretation of these goals and tested it in Brazil. As a result, it was found that many economically developed territories have a low degree of stability [11].

The data on the regions of the countries participating in the China One Belt One Road project revealed the factors influencing net savings as a characteristic of sustainable development. Health care expenditures, age structure, population size have a positive impact; negatively - the size of government and e-government [12]. The corresponding characteristics can be used in regional strategies as a metric of their sustainability.

However, at present, no methods have been developed to assess adherence to the relevance of regional strategies to the principles of sustainable development, to compare them with each other according to some criteria (more objective than expert opinions). Therefore, the purpose of our study is to develop a methodology for assessing the adherence of regional strategies to the principles of sustainable development and to test it.

\section{Research methodologies}

The provisions of the theory of strategy and the methodology of strategizing of the scientific school of V.L. Kvint [13, 14]. The authors took into account the following main methodological provisions:

1. The focus of any strategy should be on the person and the quality of his life, and the strategy should correspond to the values of the socio-economic system.

2. The essence of the strategy is the realization of the competitive advantages of the strategizing object (in this case, the region), allowing to get ahead of competitors in one parameter or another (quality, cost, timing, etc.).

3. In the conditions of emerging markets, special attention should be paid to the safety of the strategized object and the risk management system.

Further, when developing a methodology for assessing the commitment to a sustainable development strategy, the authors proceeded from the fact that it directly depends on the presence of keywords (descriptors) in the text that reflect the concept and goals of sustainable development. In accordance with this, descriptors were selected that characterize the degree of commitment of the regional strategy to the concept and goals of sustainable development.

At the same time, the authors took into account that for the overwhelming majority of regions of Russia with a high and medium level of development, such sustainable development goals as "Eradication of poverty", "Eradication of hunger", etc. are not so relevant. In the presence of serious socio-economic problems, these goals are still irrelevant for Russia; they seem to be significant only for developing countries. The goal of preserving marine ecosystems, in turn, can only be set in coastal regions. Also, individual sustainable development goals are related to the issues of the federal center and cannot be resolved at the regional level. Table 1 shows the selected descriptors for the study.

Using the data in Table 1, the study calculated the occurrence of descriptors reflecting various aspects of sustainable development in the strategies of socio-economic development of regions (in general and for individual goals). Since the strategies of socioeconomic development of different regions have a different volume (by the number of pages, words, signs), the relative frequency of occurrence was calculated. It is the ratio of the number of sustainability descriptors in the document to the total number of words. This did not take into account applications as supporting materials that do not reflect goals and strategic priorities. 
Table 1. Descriptors reflecting the commitment of the region's strategy to the principles and goals of sustainable development.

\begin{tabular}{|c|c|}
\hline $\begin{array}{c}\text { Basis for the formulation of } \\
\text { descriptors }\end{array}$ & Keywords, phrases \\
\hline $\begin{array}{c}\text { The concept of "sustainable } \\
\text { development" }\end{array}$ & $\begin{array}{c}\text { Sustainable + development; stability; future + } \\
\text { generations; harmonious; balanced }\end{array}$ \\
\hline Goal 3. Good health and well-being & Health; mortality; health care \\
\hline Goal 4. Quality education & Education; competence; \\
\hline Goal 6. Clean water and sanitation & Drinking + water; water use \\
\hline Goal 7. Affordable and clean energy & Energy efficiency; energy saving; power supply \\
\hline $\begin{array}{l}\text { Goal 8. Decent work and economic } \\
\text { growth }\end{array}$ & Employment; unemployment; decent + work \\
\hline $\begin{array}{c}\text { Goal 9. Industrialization, innovation } \\
\text { and infrastructure }\end{array}$ & Infrastructure; investments; research + development \\
\hline Goal 11. Sustainable cities and towns & Housing; city + transport \\
\hline $\begin{array}{l}\text { Goal 12. Responsible consumption } \\
\text { and production }\end{array}$ & Waste \\
\hline Goal 13. Combat climate change & $\begin{array}{l}\text { Green (economy, technology); climate; carbon + } \\
\text { economy }\end{array}$ \\
\hline $\begin{array}{l}\text { Goal 15. Conserve terrestrial } \\
\text { ecosystems }\end{array}$ & $\begin{array}{l}\text { Ecosystem; subsoil use; forest management; biodiversity } \\
\text { (biological + diversity) }\end{array}$ \\
\hline
\end{tabular}

For a comparative assessment of the adherence to the regional strategy to the principles and goals of sustainable development, the occurrence indicators are used in general for all descriptors, for the descriptors of the concept of "sustainable development", for individual sustainable development goals. As empirical material for approbation of the methodology, three variants of the strategy of socio-economic development of the Kemerovo region Kuzbass were used, for which the problems of sustainable development are extremely important:

1. "Strategy for the socio-economic development of the Kemerovo region until 2025" (adopted in 2008).

2. "Strategy for the socio-economic development of the Kemerovo region until 2035" (adopted in 2018).

3 . The revised "Strategy for the socio-economic development of the Kemerovo region Kuzbass until 2035" (adopted in 2020, in 2019 the Kemerovo region as an administrative territory was renamed into the Kemerovo region - Kuzbass).

Content analysis was carried out in the Wordstat program, other statistical calculations in the SPSS 19.0 program.

\section{Research results}

The main volumetric characteristics of the three strategies are shown in Table 2. The data in Table 2 show that the strategies for 2018 and 2020 are significantly smaller in volume than the earliest version of 2008. The discrepancy in the number of pages is still not so great due to different formatting formats - font size, spacing (average differences are about 25 pages, the coefficient of variation is about $13.5 \%$ ), but this parameter can be considered technical.

Objective volumetric characteristics differ much more strongly - the number of words and characters with spaces. They are independent of the selected styling options. In this 
case, the variants of 2018 and 2020 differ little from each other (about 5-10\%), they have about 50 thousand words and about $400-450$ thousand characters, including spaces. The 2008 version was much longer: more than 90 thousand words and almost 850 thousand characters.

Table 2. Descriptive statistics on three options for the development strategy of the Kemerovo Region - Kuzbass.

\begin{tabular}{|c|c|c|c|}
\hline & $\begin{array}{c}\text { Number of } \\
\text { words, units }\end{array}$ & $\begin{array}{c}\text { Number of characters with } \\
\text { spaces, thousand units }\end{array}$ & $\begin{array}{c}\text { Number of } \\
\text { pages, units }\end{array}$ \\
\hline Option 2008 & 93005 & 846.5 & 233 \\
\hline Option 2018 & 53585 & 436.8 & 171 \\
\hline Option 2020 & 48530 & 411.9 & 186 \\
\hline Mean & 48780 & 565.1 & 197 \\
\hline $\begin{array}{c}\text { Average linear } \\
\text { deviation }\end{array}$ & 24515 & 187.6 & 24 \\
\hline $\begin{array}{c}\text { Standard } \\
\text { deviation }\end{array}$ & 33009 & 199.2 & 26 \\
\hline $\begin{array}{c}\text { Variation } \\
\text { coefficient, } \\
\text { percent }\end{array}$ & 67.67 & & 13.43 \\
\hline
\end{tabular}

The explanation for this phenomenon lies in the fact that in 2008 the process of developing strategies for Russian regions had just begun. There was a lack of practical experience, as well as regulatory and methodological requirements for the content of the strategy. In these circumstances, strategy developers sought to cover as many issues, problems, strategic goals and objectives as possible. In accordance with this, the volume of strategic planning documents increased.

By the second round of developing strategies for the development of Russian regions (from about 2016-2018), a law "On strategic planning in the Russian Federation" had already been created, the government submitted regulatory and methodological documents that established requirements for the content of strategic planning documents and their structure. In addition, along with the strategy for the socio-economic development of the region, an action plan for its implementation was compiled.

Along with this, in the period from 2006-2008 to 2016-2018 in most regions, strategic documents were adopted for the development of individual industries, intersectoral complexes, municipalities (urban districts and municipal districts). This freed the second round strategies from unnecessarily detailed materials by industry and municipalities.

The experience of creating and implementing regional strategies of the first round was also analyzed and summarized. All this made it possible to determine the rational content of the strategy for the socio-economic development of the region and exclude unnecessary ones. Modern strategies are more compact, which makes them easier to perceive and allows you to focus on the main thing.

Let us consider the occurrence of the terms characterizing sustainable development in various variants of the development strategy of the Kemerovo region - Kuzbass. The corresponding data are shown in Table 3. The results of content analysis show that different options for strategies differ significantly in the number of descriptors associated with sustainable development. In the 2018 version, there are 1.4 times more such descriptors, even in absolute terms, than in the 2008 version, although the second document is almost twice as large as the first. Even more descriptors associated with sustainable development 
are found in the 2020 version. At the same time, a different situation is possible for individual goals: the 2008 version contains the largest number of descriptors for the "Affordable and Clean Energy" goal.

Table 3. The occurrence of descriptors reflecting the commitment to the principles and goals of sustainable development for various options for the strategy of the Kemerovo Region - Kuzbass (by the number of words).

\begin{tabular}{|c|c|c|c|}
\hline & $\begin{array}{c}\text { Option } \\
\mathbf{2 0 0 8}\end{array}$ & $\begin{array}{c}\text { Option } \\
\mathbf{2 0 1 8}\end{array}$ & $\begin{array}{c}\text { Option } \\
\mathbf{2 0 2 0}\end{array}$ \\
\hline The concept of "sustainable development" & 39 & 24 & 44 \\
\hline Goal 3. Good health and well-being & 18 & 90 & 60 \\
\hline Goal 4. Quality education & 106 & 169 & 34 \\
\hline Goal 6. Clean water and sanitation & 7 & 78 & 209 \\
\hline Goal 7. Affordable and clean energy & 135 & 88 & 64 \\
\hline Goal 8. Decent work and economic growth & 45 & 42 & 68 \\
\hline Goal 9. Industrialization, innovation and \\
infrastructure & 65 & 138 & 292 \\
\hline Goal 11. Sustainable cities and towns & 100 & 81 & 122 \\
\hline Goal 12. Responsible consumption and \\
production & 3 & 42 & 124 \\
\hline Goal 13. Combat climate change & 13 & 26 & 76 \\
\hline Goal 15. Conserve terrestrial ecosystems & 41 & 24 & 104 \\
\hline Total by descriptors of sustainable development & 572 & 802 & 1197 \\
\hline
\end{tabular}

Of course, a direct comparison of the absolute number of descriptors has many research limitations due to the different scope of different variants of the Kemerovo Oblast Kuzbass strategy. Therefore, in accordance with the method proposed above, the relative frequency of occurrence of descriptors was calculated. For convenience of analysis, since descriptors of sustainable development are not so often found in the text, not percentages were used, but prodecymille (one ten thousandth or one hundredth of a percent). The calculation results are shown in Table 4.

The data obtained indicate that more and more attention is paid to the issues of sustainable development in the development strategies of the region. If in the 2008 version, 61.5 were associated with sustainable development by ten thousand words, then in $2018-$ almost 150, and in 2020 - almost 400, there was an increase of more than 6 times. The increase was especially significant for the goals "Clean water and sanitation" (almost 60 times), "Responsible consumption and production" (about 80 times), "Fight against climate change" (more than 11 times). Thus, all three strategy options have consistently become more and more committed to the principles and goals of sustainable development.

Variant 2018 compared to variant 2008 showed an increase in resistance descriptors in all categories, although the growth was not uniform. Thus, much more attention has been paid to "good health and well-being", "quality education", "clean water", "responsible consumption and production". There have been no significant changes for goals such as "Affordable and Clean Energy" and "Conservation of Terrestrial Ecosystems". 
Table 4. The occurrence of descriptors reflecting adherence to the principles and goals of sustainable development for various options for the strategy of the Kemerovo Region - Kuzbass (in prodecymille).

\begin{tabular}{|c|c|c|c|c|c|}
\hline & $\begin{array}{c}\text { Option } \\
\mathbf{2 0 0 8}\end{array}$ & $\begin{array}{c}\text { Option } \\
\mathbf{2 0 1 8}\end{array}$ & Growth & $\begin{array}{c}\text { Option } \\
\mathbf{2 0 2 0}\end{array}$ & Growth \\
\hline $\begin{array}{c}\text { The concept of "sustainable } \\
\text { development" }\end{array}$ & 4.19 & 4.48 & 0.29 & 9.07 & 20.00 \\
\hline $\begin{array}{c}\text { Goal 3. Good health and well- } \\
\text { being }\end{array}$ & 1.94 & 16.80 & 14.86 & 12.36 & $(30.00)$ \\
\hline Goal 4. Quality education & 11.40 & 31.54 & 20.14 & 7.01 & $(135.00)$ \\
\hline Goal 6. Clean water and sanitation & 0.75 & 14.56 & 13.80 & 43.07 & 131.00 \\
\hline $\begin{array}{c}\text { Goal 7. Affordable and clean } \\
\text { energy }\end{array}$ & 14.52 & 16.42 & 1.91 & 13.19 & $(24.00)$ \\
\hline $\begin{array}{c}\text { Goal 8. Decent work and } \\
\text { economic growth }\end{array}$ & 4.84 & 7.84 & 3.00 & 14.01 & 26.00 \\
\hline $\begin{array}{c}\text { Goal 9. Industrialization, } \\
\text { innovation and infrastructure }\end{array}$ & 6.99 & 25.75 & 18.76 & 60.17 & 154.00 \\
\hline $\begin{array}{c}\text { Goal 11. Sustainable cities and } \\
\text { towns }\end{array}$ & 10.75 & 15.12 & 4.36 & 25.14 & 41.00 \\
\hline $\begin{array}{c}\text { Goal 12. Responsible } \\
\text { consumption and production }\end{array}$ & 0.32 & 7.84 & 7.52 & 25.55 & 82.00 \\
\hline Goal 13. Combat climate change & 1.40 & 4.85 & 3.45 & 15.66 & 50.00 \\
\hline $\begin{array}{c}\text { Goal 15. Conserve terrestrial } \\
\text { ecosystems }\end{array}$ & 4.41 & 4.48 & 0.07 & 21.43 & 80.00 \\
\hline $\begin{array}{c}\text { Total by descriptors of sustainable } \\
\text { development }\end{array}$ & 61.50 & 149.67 & 88.17 & 246.65 & 395.00 \\
\hline
\end{tabular}

Consequently, the second version of the strategy of socio-economic development of the Kemerovo region - Kuzbass is characterized by a higher degree of attention to health and education, industrialization and infrastructure. The rise in the frequency of all sustainable development-related descriptors also demonstrates the higher commitment of the 2018 option to the principles and goals of sustainable development.

To assess the statistical significance of the positive dynamics of the occurrence of sustainable development descriptors in the 2018 version as compared to the previous one, the Wilcoxon T-test was calculated, which allows solving this problem. The null hypothesis was that in the 2018 strategy version, all categories of sustainable development descriptors were encountered more often than in the 2008 version. The calculations showed that the actual value of the Wilcoxon T-test is 0.00 . In this case, the tabular value at the significance level of 0.05 is 13.00 . Since the zone of significance extends to the left, the ratio of the tabular and critical values allows us to confirm the null hypothesis. The Kemerovo Oblast Kuzbass Strategy 2018 was more committed to the goals and principles of sustainable development than the 2008 strategy.

The 2020 strategy also places greater emphasis on various aspects of sustainable development. Descriptors for the goals "Clean water and sanitation", "Industrialization, innovation and infrastructure", "Responsible consumption and production", "Combating climate change" are much more common. At the same time, the incidence of descriptors associated with good health and well-being, education and energy decreased.

The Wilcoxon T-test was also used to assess the statistical significance of the changes. Its actual value was 12.00 . As in the previous case, the null hypothesis was confirmed - the 2020 version is more committed to the goals and principles of sustainable development compared to its predecessor. 


\section{The discussion of the results}

The results of the study show that the commitment to different options for the strategy of socio-economic development of the Kemerovo region - Kuzbass in 2008-2020 grew monotonously. The 2018 version contained $40.2 \%$ more sustainable development descriptors than the previous one, and the 2020 version - by $49.3 \%$, although the volume of these documents decreased. This fact can have several explanations.

First, the objective socio-economic situation in the region, key problems, strategic priorities, as well as the external environment has changed. According to scientists from the Kemerovo Region - Kuzbass and Siberia, by 2018 the situation in the region had significantly deteriorated compared to 2008, and the stability of the economy decreased. In particular, ecological, demographic problems, problems in the field of nature management have worsened [15]. Adjusted net savings in the region were negative, with economic growth driven largely by the exploitation of natural resources. The dependence of the Kemerovo region - Kuzbass on the coal industry has increased, and it was not possible to diversify the economy.

Therefore, the creators of the 2018 version of the strategy were forced to pay much more attention to such a topic as health, due to the aging of the region's population, worsening of the situation with morbidity, and insufficient life expectancy. A serious aggravation of the ecological situation (for example, the concentration of almost $50 \%$ of the country's solid industrial waste on the territory of the Kemerovo region - Kuzbass) has also led to an increase in the occurrence of terms associated with responsible consumption and production. Another major strategic goal, the diversification of the economy, has caused a significant increase in the number of descriptors for the goal "Industrialization, innovation and infrastructure".

At the same time, this trend is not typical for all sustainable development goals. Thus, the occurrence of descriptors associated with the energy supply of the regional economy has practically not changed. This is already due to situational factors - in 2008 there was a campaign on energy saving and energy efficiency at the national level. In 2018, interest in this topic dropped significantly.

Secondly, the commitment of a strategy to sustainable development goals depends on the developers themselves, their professionalism and the methodology used (or lack thereof). Practice shows that the development of regional strategies is often (more precisely, in most cases) forced to deal with people who are not specialized specialists in this area. With their high qualifications in their professional field and motivation, there is a shortage of strategic competencies. This affects the architectonics and content of the strategies.

Therefore, it is of interest to compare the options for the development strategy of the Kemerovo Region - Kuzbass in 2018 and 2020. Such a quick adjustment of the strategy, of course, is largely due to the external shock - the spread of the new coronavirus infection COVID-19 and the economic crisis. However, it is also important that the 2020 version was drawn up by specialized specialists of the Moscow State University named after M.V. Lomonosov (head of work, Academician of the RAS V.L. Kvint). All this led to a change in the approach to sustainable strategic development of the region.

At first glance, the decrease in the occurrence of descriptors related to the health of the population, as well as the education system, may raise questions. However, an analysis of the content of the 2018 strategy version shows that it deals with solving the most pressing problems of regional health care, and not with its strategic development. In other words, strategy is, in a sense, replaced by tactics. In accordance with the theory of strategy and strategy methodology, solving current problems cannot and should not be part of the strategy. The 2020 version, of course, contains a strategic vision and strategic priorities for 
education and health care in the Kemerovo Oblast - Kuzbass, but in the long term, and not at the tactical level.

At the same time, for many sustainable development goals, the occurrence of the corresponding terms has increased. Much more attention is paid to the creation of infrastructure, new industrialization of the region's economy in connection with the urgent need for diversification. The structure and dynamics of investment projects in the Kemerovo Region - Kuzbass for 2020-2021 already confirms the correctness of the chosen priorities.

Much more often, in the 2020 version, the problem of preserving terrestrial ecosystems is traced, which was not paid enough attention in the 2018 version (there, for the most part, only land reclamation was considered, which also refers to tactics, not strategy). Finally, the frequency of mentioning descriptors related to clean water, one of the most important topics of our time, has significantly increased.

\section{Conclusions}

Sustainable development of the region as part of the national and global economy is possible only if a strategy is implemented that is committed to the goals and principles of sustainability. The study develops and tests a methodology for assessing the strategy's commitment to sustainable development goals based on content analysis. The results showed that the occurrence of descriptors associated with sustainable development is constantly growing.

Comparison of three variants of the strategy of socio-economic development of the Kemerovo region - Kuzbass (2008, 2018, and 2020) showed that the absolute increase exceeded 6 times, and the relative frequency of occurrence increased by $40.2 \%$ and $49.3 \%$, respectively. Development strategies for the region are becoming increasingly committed to the principles and goals of sustainable development, although uneven growth has been observed across different goals. For example, in the 2018 version, the incidence of descriptors associated with responsible production and consumption, health, and education has sharply increased, which is due to the objective problems of the Kemerovo region Kuzbass.

Another factor influencing the change in the occurrence of different categories of descriptors is the use of different theoretical and methodological foundations of strategizing (or ignoring them). The 2020 version, developed by professional strategists, excluded from consideration tactical issues and current problems that are not the object of strategic management. Therefore, the number of descriptors related to education and healthcare has decreased to a reasonable level (where some of the problems in 2020 compared to 2018 have already been resolved). The frequency of mentioning such important goals as clean water, infrastructure development, responsible production and consumption, and the fight against climate change has increased significantly.

\section{References}

1. R. Jovovic, M. Draskovic, M. Delibasic, M. Jovovic, Journal of International Studies, 10 (1) (2017)

2. H. Koff, C. Maganda, Regions and Cohesion, 10 (1) (2020)

3. Y. Friedman, G. Rechko, E. Loginova, Regional Research of Russia, 10 (4) (2020)

4. H. Wei, M. Nian, L. Li, Chinese Journal of Urban and Environmental Studies, 8 (2) (2020) 
5. G. Haughton, D. Counsell, The Geographical Journal, 170 (2) (2004)

6. G. Haughton, D. Counsell, Environment and Planning C: Government and Policy, 21 (2) (2003)

7. C. Hirschi, Ecology and Society, 15 (4) (2010)

8. A. Shahraki, Frontiers of Architectural Research, 8 (4) (2019)

9. M. Szabó, M. Csete, T. Pálvölgyi, European Journal of Sustainable Development, 7 (1) (2018)

10. A. Frank, T. Marsden, Metropolitan Ruralities, 23 (1) (2016)

11. J. Rezende, M. Sinay, Revista de Administração Pública, 50 (3) (2016)

12. A. Ullah, C. Pinglu, S. Ullah, S. Hashmi, PLoS ONE, 16 (7) (2021)

13. V. Kvint, Strategy for the Global Market: Theory and Practical Applications (2016)

14. V. Kvint, The Global Emerging Market: Strategic Management and Economics (2009)

15. V. Kryukov, Y. Fridman, E. Loginova, G. Rechko, ECO, 48 (11) (2018) 